\title{
SMA Tunas Mekar Indonesia Tangguh Bencana
}

\author{
Neneng*1, Ajeng Savitri Puspaningrum² ${ }^{2}$, Fera Lestari³ ${ }^{3}$ Dian Pratiwi ${ }^{4}$ \\ 1,2,3,4 Universitas Teknokrat Indonesia \\ 1,2,3Fakultas Teknik dan Ilmu Komputer, Universitas Teknokrat Indonesia \\ *e-mail: neneng@teknokrat.ac.id ${ }^{1}{ }^{\text {}}$ ajeng.savitri@teknokrat.ac.id ${ }^{2}{ }_{\text {.fera.lestari@teknokrat.ac.id }}^{3}$
}

Nomor Handphone Untuk keperluan koordinasi : 0857-6951-5089

\begin{abstract}
Abstrak
Faktor utama penyebab adanya korban akibat bencana seperti gempa bumi dan kebakaran adalah kurangnya pengetahuan masyarakat tentang bencana serta kesiapan mereka dalam mengantisipasi bencana tersebut. Sekolah merupakan salah satu media penyaluran ilmu pengetahuan yang sangat efektif dalam menyerap dan mengaplikasikan pengetahuan kesiapan dalam menghadapi bencana dengan metode yang tepat dan benar. Selain itu dalam proses akreditasi, permasalahan yang terjadi di SMA Tunas Mekar Indonesia (TMI) adalah belum tersedianya jalur evakuasi dan pelatihan kebencanaan. Untuk itu tim melakukan kegiatan pengabdian kepada masyarakat berupa pemasangan tanda jalur evakuasi dan pelatihan kebencanaan bagi SMA TMI untuk meningkatkan kesiapan sivitas akademika sekolah serta membantu meningkatkan nilai akreditasi bagi sekolah. Metode pengumpulan data yang digunakan adalah wawancara dan survey. Hasil dari kegiatan ini adalah jalur evakuasi dan peningkatan pengetahuan terhadap kebencanaan sebesar $24,62 \%$.
\end{abstract}

Kata kunci: SMA, pelatihan kebencanaan, jalur evakuasi

\begin{abstract}
The main factor causing victims of disasters such as earthquakes and fires is the lack of public knowledge about disasters and their preparedness in anticipating such disasters. Schools are one of the most effective knowledge distribution media in absorbing and applying disaster preparedness knowledge with the right and correct methods. In addition, in the accreditation process, problems that occur at SMA Tunas Mekar Indonesia (TMI) are the unavailability of evacuation routes and disaster training. For this reason, the team carried out community service activities in the form of installing evacuation route signs and disaster trainingfor TMI SMA to improve the readiness of the school's academic community and help increase the value of accreditation for schools. Data collection methods used are interviews and surveys. The result of this activity is an evacuation route and an increase in knowledge of disaster by 24,62\%.
\end{abstract}

Keywords: High school, disaster training, evacuation route

\section{PENDAHULUAN}

Bencana baik kebakaran maupun gempa bumi sulit untuk diperkirakan dan diprediksi oleh kemampuan manusia tentang proses terjadinya seperti waktu, penyebab, tingkat cakupannya serta seberapa besar dampak yang ditimbulkannya [1] [2]. Bencana yang terjadi di gedung bertingkat bahkan lebih mematikan dan merugikan, selain itu penanganan bencana di lokasi gedung bertingkat lebih menyulitkan dan berisiko tinggi daripada lokasi-lokasi lain [3]. Berdasarkan penelitian [4] zonasi percepatan tanah maksimum di Wilayah Lampung dibagi menjadi 3 zona, yaitu zona pertama pada skala intensitas I-II MMI untuk Wilayah Kota Bumi dan Bandar Lampung, zona kedua pada skala intensitas III-V MMI untuk Wilayah Kota Agung, dan zona ketiga pada skala intensitas VII-VIII MMI untuk Wilayah Liwa. Selain itu, berdasarkan data pada tahun 2015, Indonesia merupakan dalam kelompok ketiga yang frekuensi kebakarannya antara 20-100 ribu kejadian pertahun dengan korban jiwa mencapai 200 hingga 1000 orang [3]. Pemerintah kota Bandarlampung juga telah mengeluarkan Peraturan Daerah (Perda) Nomor 06 Tahun 2015 Tentang Pencegahan Dan Penanggulangan Bahaya Kebakaran. Pada Perda tersebut disampaikan bahwa Setiap pemilik, pengguna dan/atau badan pengelola bangunan gedung dan lingkungan gedung yang mempunyai potensi bahaya kebakaran wajib berperan aktif dalam mencegah kebakaran [5].

Menurut Hendrik pada [6], evakuasi digambarkan seperti saat terjadi bencana pada bangunan gedung, banyak orang secara simultan berlari menuju pintu keluar, saling berdesakan 
dan mendorong untuk menyelamatkan diri dan keluar dari gedung secepat mungkin dengan menghindari rintangan yang terjadi, serta harus memilih pintu keluar yang tepat agar tidak terluka dan menjadi korban dari peristiwa tersebut. Secara sederhana evakuasi dapat didefinisikan sebagai pergerakan manusia dari suatu tempat yang terancam oleh suatu bencana ke tempat yang lebih aman. Jalur evakuasi sendiri merupakan jalan keluar yang menerus dan tidak terhalangi oleh sesuatu yang dapat dilalui pengguna bangunan menuju ke tempat yang aman, apabila terjadi bencana pada suatu bangunan. Penyiapan jalur evakuasi merupakan salah satu upaya untuk mengurangi dampak kerugian yang diakibatkan oleh bencana [7]. Namun menurut [8] hasil kajian lapangan yang telah dilakukan menunjukkan banyak bangunan yang tidak memenuhi ketentuan keselamatan evakuasi. Hal tersebut tentu meningkatkan resiko kehilangan nyawa ketika terjadi bencana. Penelitian yang telah dilakukan [2] [9] [10] menyebutkan pelatihan kebencanaan mampu meningkatkan pengetahuan, kesadaran dan kesiapsiagaan dalam menghadapi bencana.

SMA Tunas Mekar Indonesia (TMI) merupakan salah satu institusi pendidikan yang beralamat di Jl. Arif Rahman Hakim No. 30 Tanjung Baru Kedamaian Bandar Lampung. Lokasi SMA TMI yang berada pada zonasi pertama percepatan tanah maksimum dengan skala intensitas I-II MMI menjadikan institusi tersebut beresiko terkena dampak bencana gempa bumi. Selain itu, SMA TMI juga beresiko terkena dampak bencana kebakaran yang mungkin terjadi sewaktu-waktu terlebih bangunan yang digunakan sebagai tempat melakukan aktifitas merupakan gedung bertingkat seperti pada gambar 1 . Untuk mengurangi resiko bencana kebakaran dan gempa bumi, institusi perlu melakukan pemasangan jalur evakuasi serta pelatihan kebencanaan sesuai perda yang telah dikeluarkan oleh pemerintan kota setempat. Namun, berdasarkan wawancara dengan Kepala Sekolah, saat ini SMA TMI belum memiliki jalur evakuasi dan belum pernah melakukan pelatihan kebencanaan. Untuk itu, tim melakukan kegiatan pengabdian kegiatan masyarakat (PKM) berupa pemasangan jalur evakuasi serta pelatihan kebencanaan untuk mengurangi resiko yang ditimbulkan dari bencana-bencana tersebut.

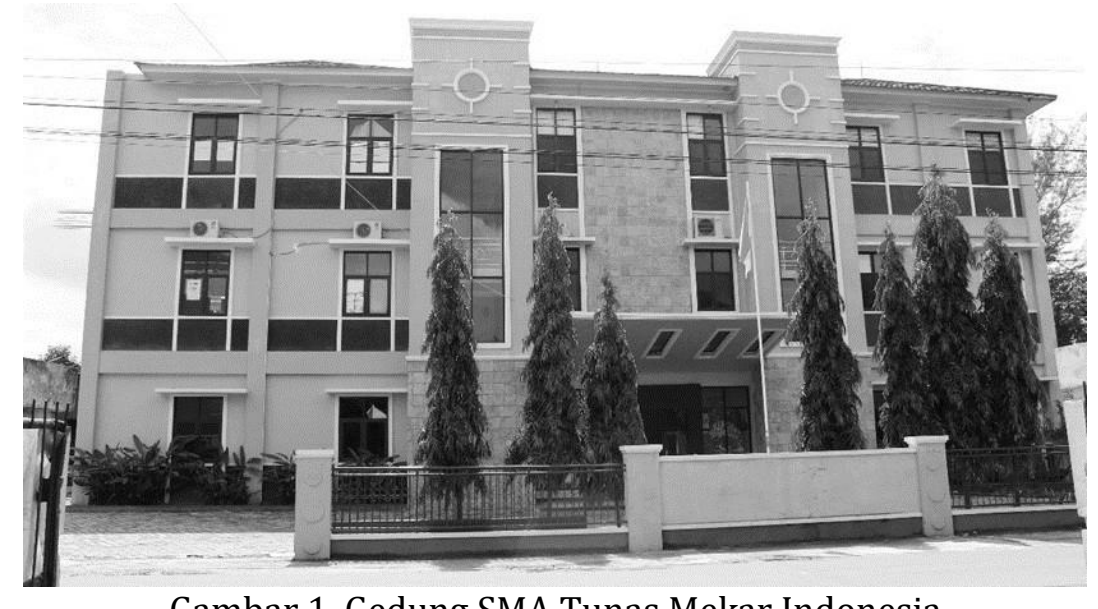

Gambar 1. Gedung SMA Tunas Mekar Indonesia

\section{METODE}

Metode yang digunakan dalam kegiatan PKM ini meliputi pendekatan individual dan partisipatif. Pendekatan individual dilakukan dengan cara berkomunikasi secara langsung untuk mengetahui kebutuhan yang diperlukan oleh mitra terkait dengan masalah yang dihadapi yakni pemasangan jalur evakuasi. Sedangkan pendekatan partisipatif dilakukan dengan melibatkan peserta pelaksanaan PKM yaitu pelatihan mitigasi bencana bagi sivitas akademika SMA TMI. Untuk pelaksanaan kegiatan PKM ini dilaksanakan melalui tiga tahapan yaitu tahapan awal, tahapan proses, dan tahapan akhir yang dapat dilihat pada gambar 2 . 


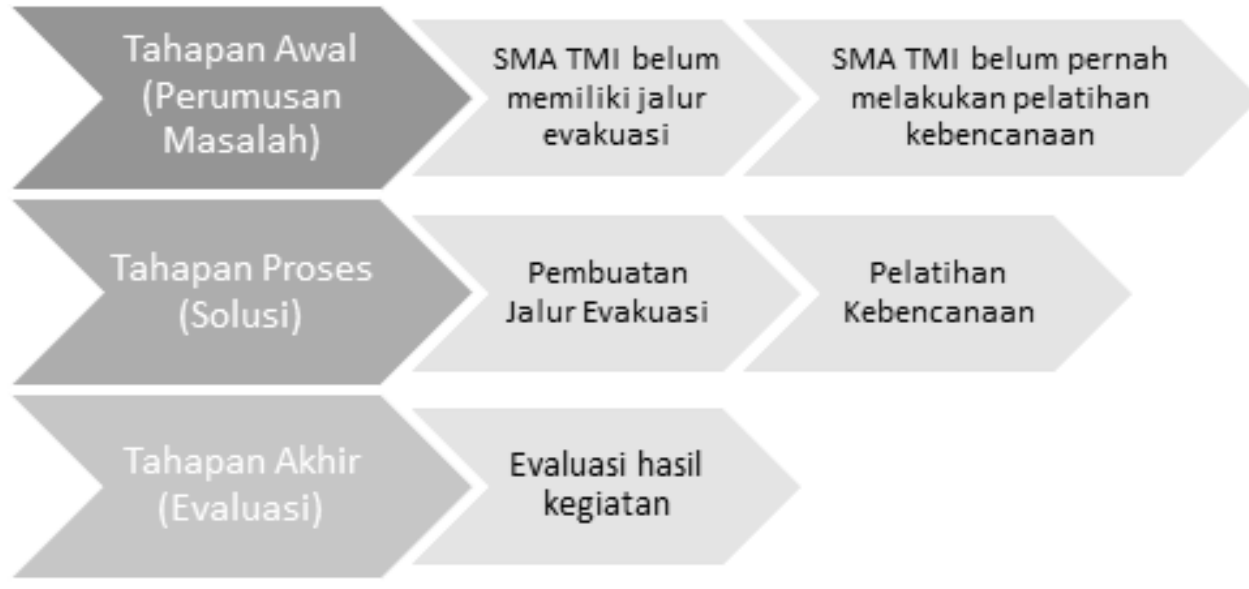

Gambar 2. Tahapan Pelaksanaan Kegiatan

\section{Tahapan Awal (Perumusan Masalah)}

Pada tahap awal kegiatan ini, dilakukan dengan pendekatan individual yaitu tim melakukan wawancara kepada pihak sekolah untuk mendapatkan permasalahan yang terjadi dan harapan dari pihak mitra.

\section{Tahapan Proses (Solusi)}

Selanjutnya tim melakukan pengumpulan data berupa servey lokasi dan dokumentasi tata letak bangunan sekolah untuk membuat solusi berupa pembuatan jalur evakuasi. Survey dilakukan untuk menentukan titik pemasangan tanda jalur arah evakusi dan titik kumpul. Kemudian tim melakukan diskusi dengan mitra untuk menentukan jadwal pelaksanaan pemasangan jalur evakuasi. Setelah jalur evakuasi dipasang, tim melaksanakan kegiatan pelatihan mitigasi bencana dengan mengundang narasumber untuk memberikan materi terkait mitigasi bencana. Kegiatan pelatihan dilakukan pada 14 Juli 2021 menggunakan pendekatan partisipatif dengan melibatkan peserta pelaksanaan PKM yaitu sivitas akademika SMA TMI yakni guru dan siswa.

\section{Tahapan Akhir (Evaluasi)}

Setelah kegiatan PKM selesai dilaksanakan maka selanjutnya dilakukan evaluasi terhadap kegiatan tersebut untuk menganalisis apakah kegiatan yang dilakukan bermanfaat dan dapat menyelesaikan masalah mitra. Evaluasi dilakukan dengan menyebarkan kuisioner kepada sivitas akademika SMA TMI.

\section{HASIL DAN PEMBAHASAN}

Hasil dari kegiatan PKM yang dilaksanakan adalah jalur evakuasi bagi SMA Tunas Mekar Indonesia berupa tanda jalur evakuasi dan titik kumpul yang telah terpasang pada titik-titik yang telah ditentukan. Selanjutnya dilakukan pelatihan mitigasi bencana untuk meningkatkan pengetahuan dan kesiapsiagaan terhadap bencana bagi sivitas akademika SMA TMI.

\section{Survey Jalur Evakuasi}

Survey pemasangan jalur evakuasi dan dokumentasi bangunan dilakukan pada tanggal 31 Maret 2021 di SMA TMI. Bangunan yang digunakan SMA TMI dalam melakukan kegiatan aktifitas belajar mengajar merupakan bangunan bertingkat 3 dengan luas wilayah \pm 1 ha yang digunakan secara bersama dengan SMP Tunas Mekar Indonesia. Kegiatan survey dan dokumentasi bangunan dapat dilihat pada gambar 3 dan gambar 4.

Dari kegiatan survey diketahui bahwa untuk kegiatan tingkat SMA dilakukan hanya pada lantai 1 dan lantai 2 yang terdiri dari :

1. Lantai. 1 : 2 Ruang Kelas, 1 Lobby, 1 Ruang Kepala sekolah, 1 Ruang Sekretaris, 1 Ruang Kesehatan, 2 Toilet, 2 Ruang Keagamaan, 1 Ruang OSIS, 1 Ruang Kantin, dan 1 Lapangan.

2. Lantai 2 : 5 Ruang Kelas, 1 Ruang Multimedia, 1 Ruang BK, 1 Ruang Guru, 1 Ruang Keagamaan, 4 Toilet 


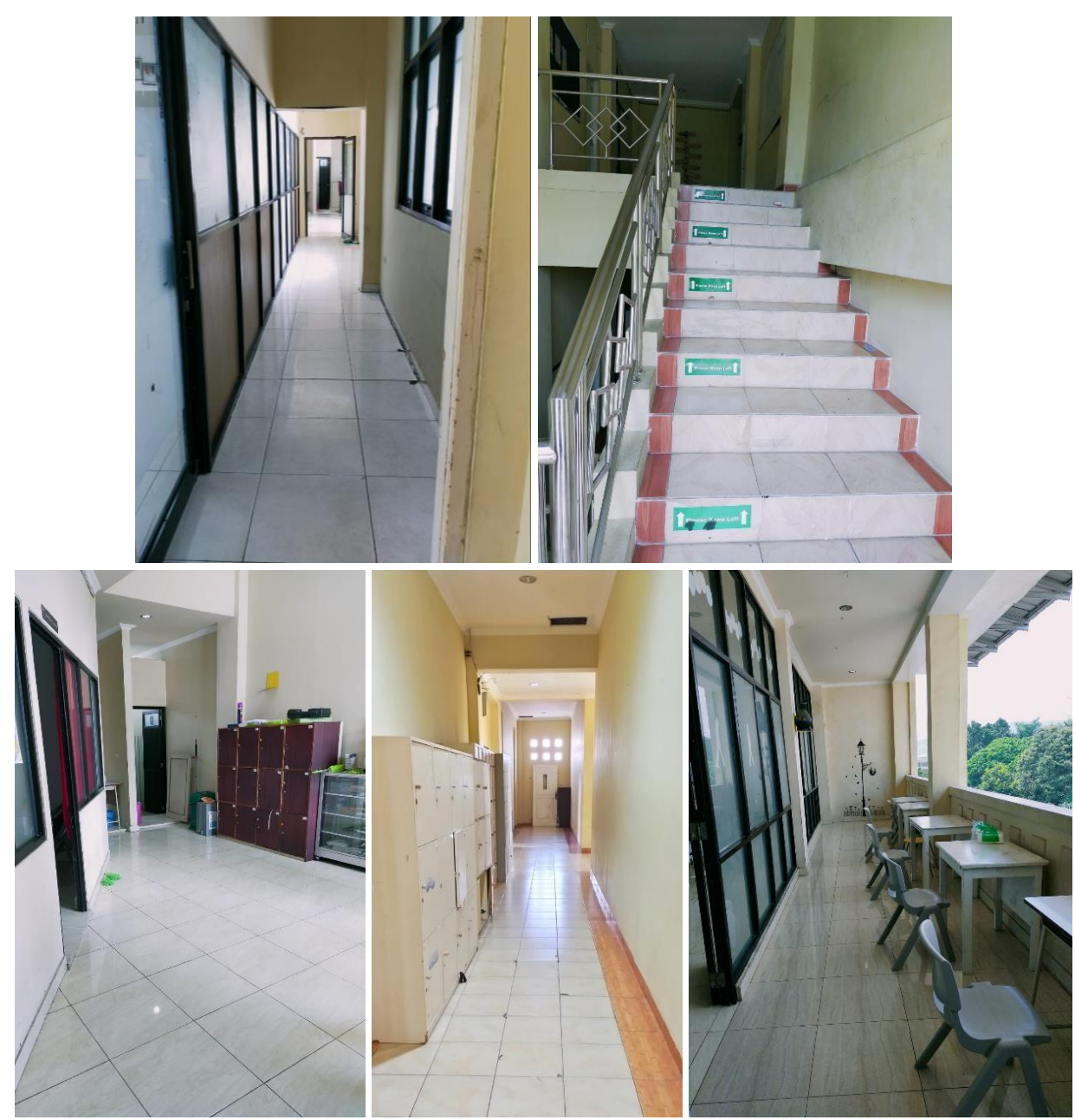

Gambar 3. Survey bangunan sekolah

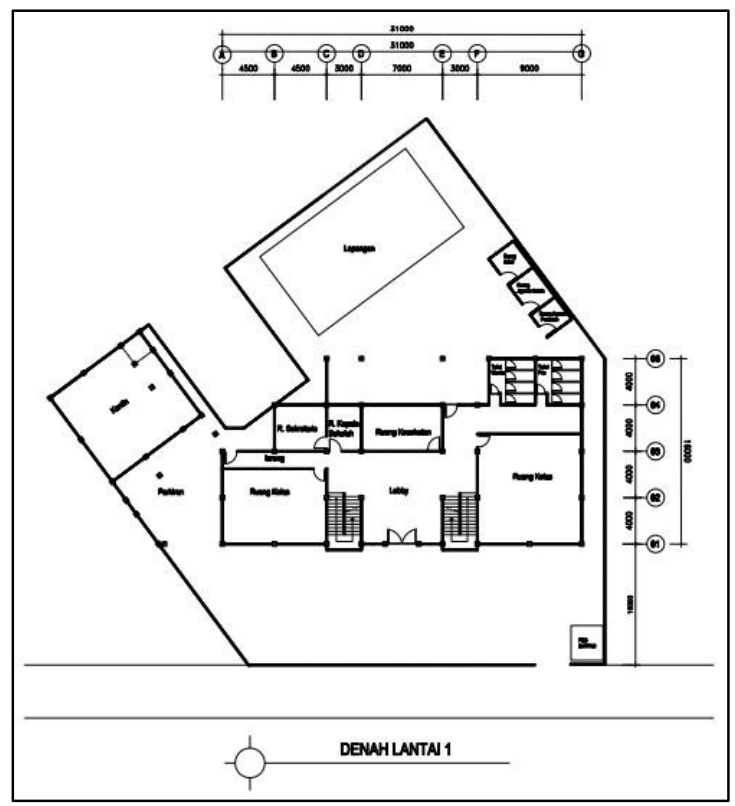

Gambar 4. Denah Ruang Bangunan Sekolah

\section{Pemasangan Jalur Evakuasi}

Dari hasil survey dan dokumentasi yang telah dilakukan, tim selanjutnya menyusun jalur evakuasi dan menentukan titik pemasangan penunjuk tanda jalur evakuasi serta titik kumpul. Peta jalur evakuasi yang disusun dapat dilihat pada gambar 5 . 


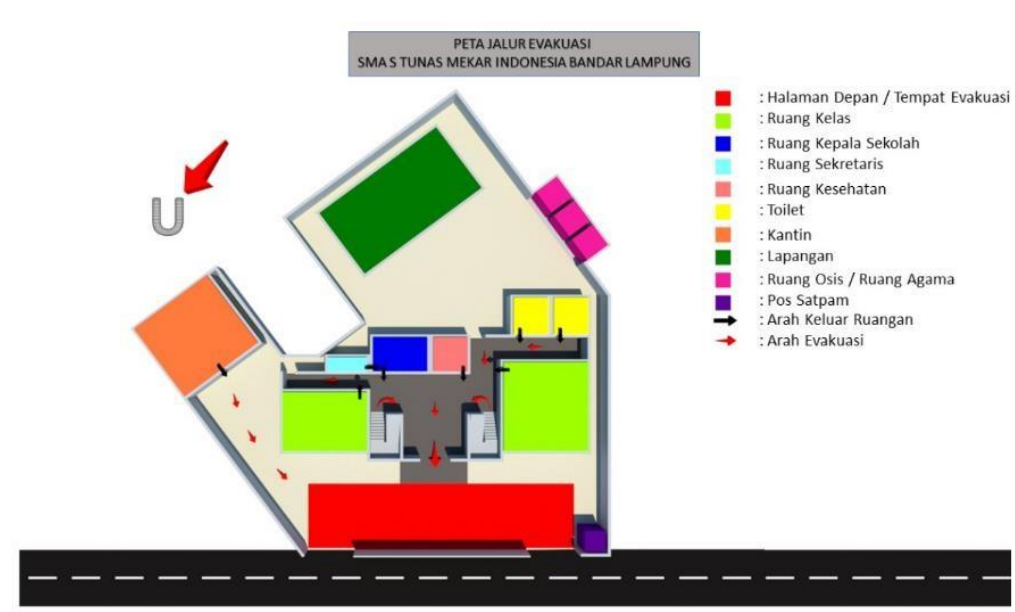

Gambar 5. Peta jalur evakuasi SMA Tunas Mekar Indonesia

Setelah jalur evakuasi ditentukan, berikutnya adalah pemasangan tanda jalur evakuasi dan titik kumpul yang dilakukan pada tanggal 10 Juni 2021. Dokumentasi kegiatan tersebut dapat dilihat pada gambar 6 dan 7 .

\section{Pelatihan Kebencanaan}

Setelah tanda jalur evakuasi terpasang, tim selanjutnya merencanakan pelaksanaan pelatihan mitigasi bencana. Pelatihan dilakukan melalui aplikasi Zoom Meeting karena saat jadwal pelaksanaan pemerintah kota menerapkan Pemberlakuan Pembatasan Kegiatan Masyarakat (PPKM) sehingga kegiatan yang direncanakan terlaksana dengan tatap muka dialihkan melalui pertemuan menggunakan media online. Pelatihan ini dilakukan pada 14 Juli 2021 dengan narasumber yaitu Ibu Dian Pertiwi, M.Eng yang mengangkat Tema "Sekolah Tangguh Bencana". Kegiatan ini diikuti oleh sivitas akademika SMA TMI yang terdiri dari Guru dan Siswa. Dokumentasi kegiatan pelatihan kebencanaan dapat dilihat pada Gambar 8.
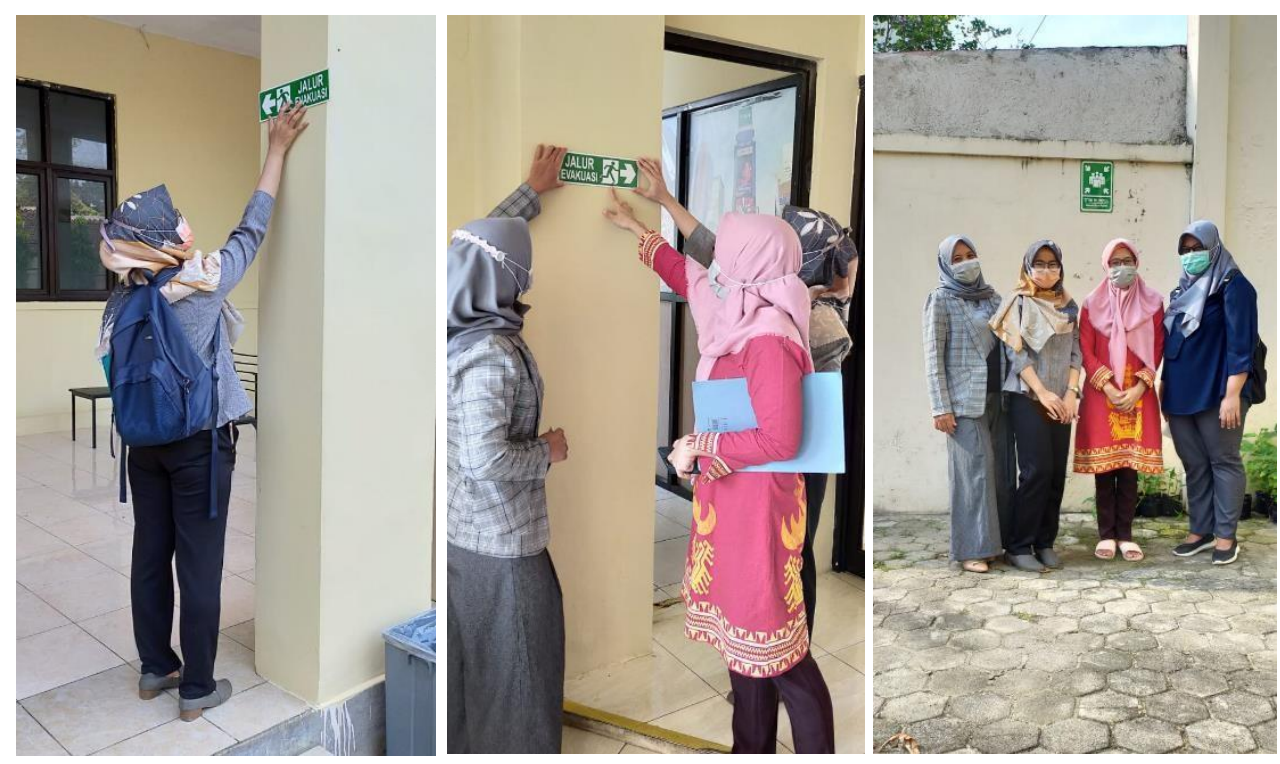

Gambar 6. Pemasangan Jalur Evakuasi 

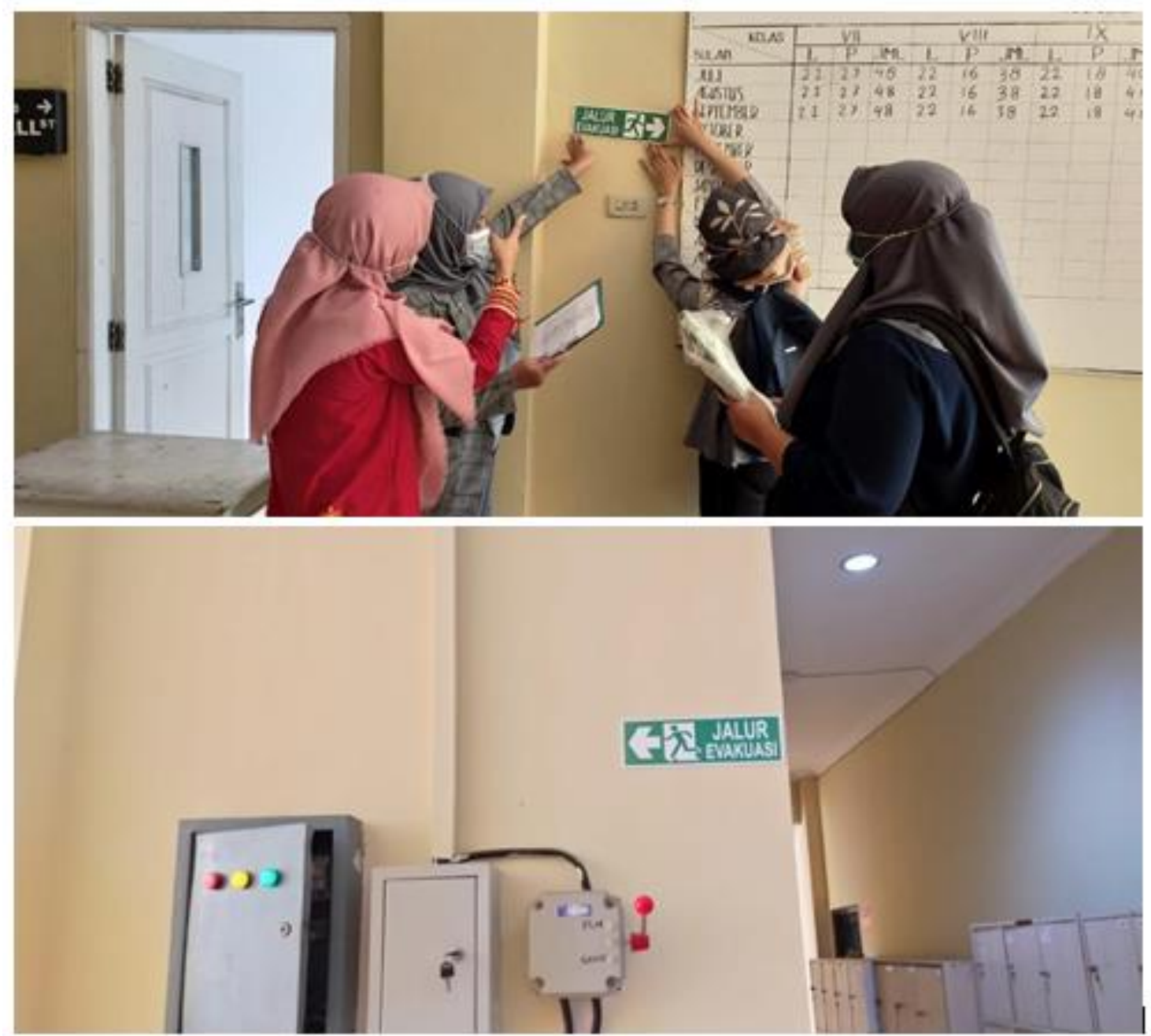

Gambar 7. Pemasangan Jalur Evakuasi

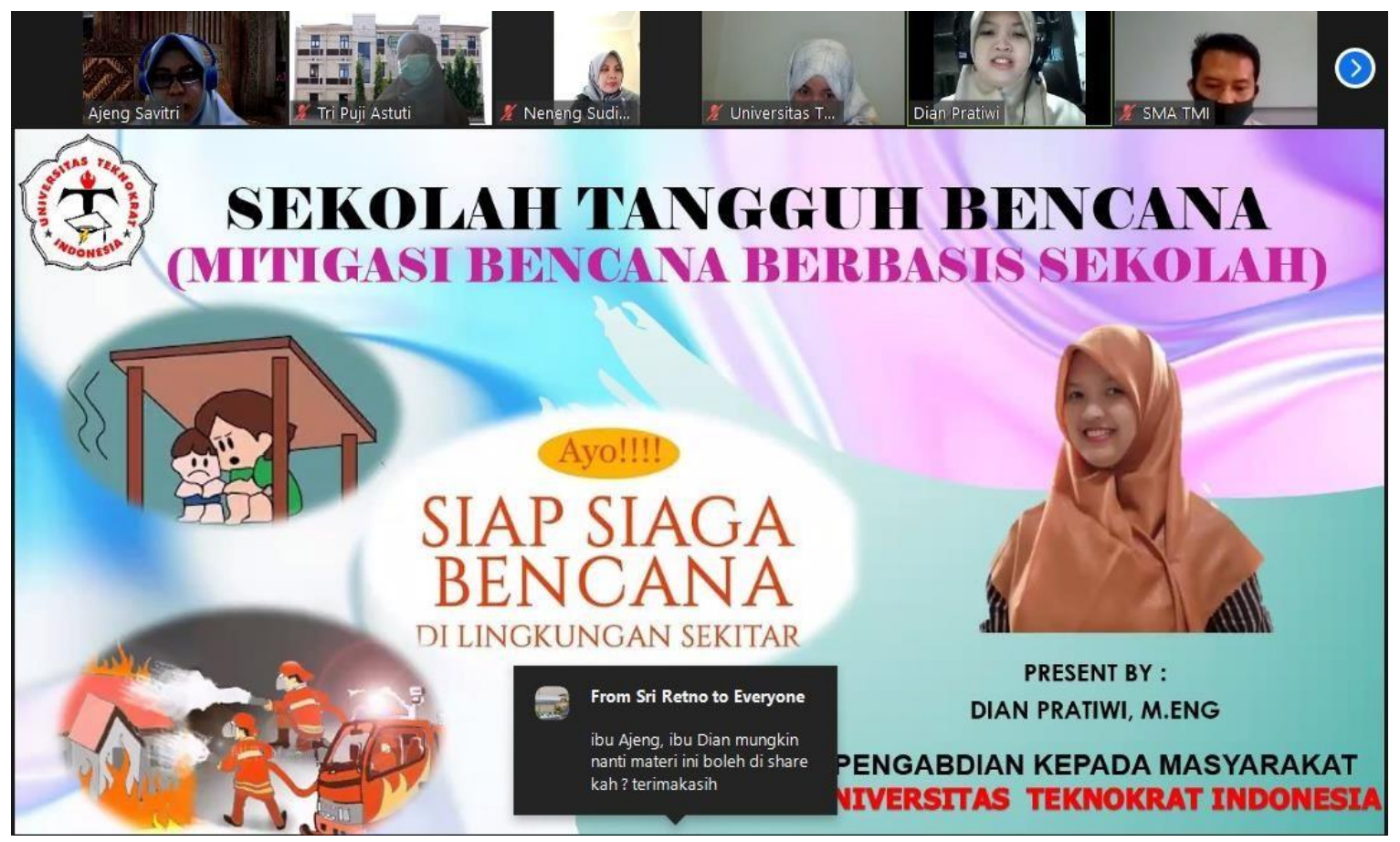




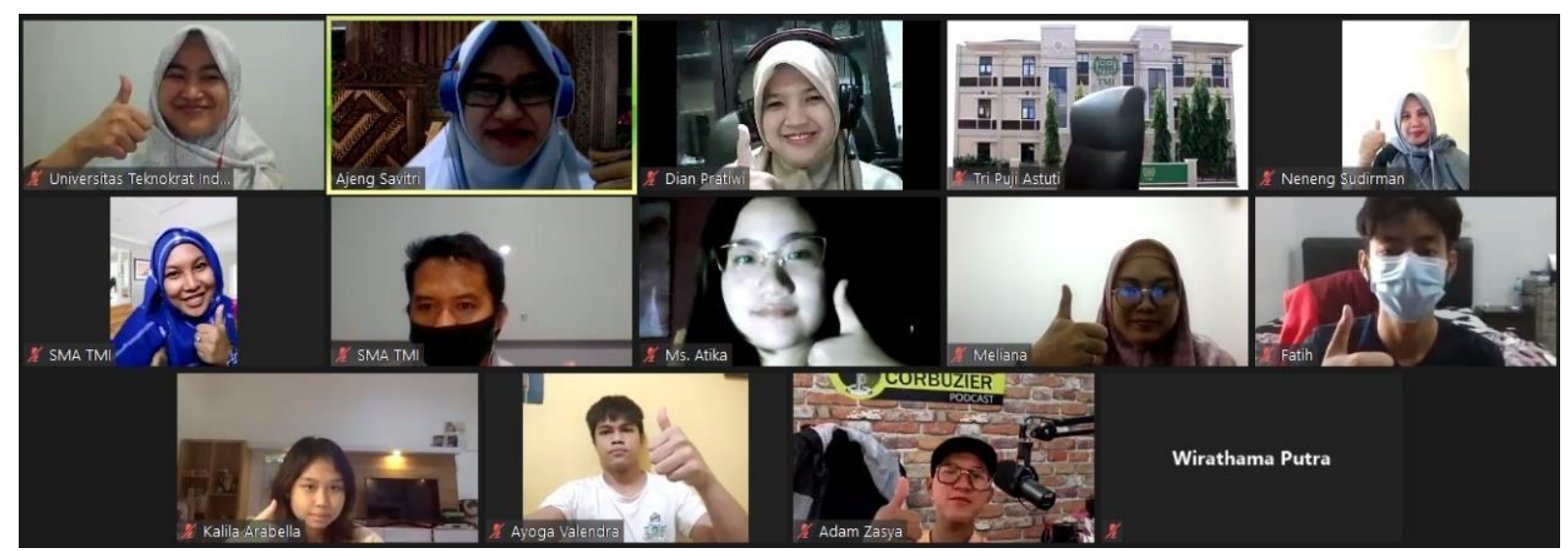

Gambar 8. Dokumentasi Kegiatan Pelatihan Kebencanaan

\section{Evaluasi Kegiatan}

Dari wawancara yang dilakukan dengan pihak sekolah, mitra antusias dengan kegiatan PKM yang dilaksanakan yaitu Penyusunan dan pemasangan jalur evakuasi serta pelatihan kebencanaan karena kegiatan ini bermanfaat bagi sekolah baik dengan harapan mampu mengurangi resiko bencana dan dampak kerugian yang diakibatkan oleh bencana serta mampu memenuhi kebutuhan akreditasi dan peraturan daerah yang berlaku. Selain itu, berdasarkan hasil evaluasi yang dilakukan sebelum dan sesudah kegiatan menggunakan kuisioner terhadap peserta pelatihan didapatkan bahwa terdapat peningkatan pengetahuan yang dapat dilihat pada tabel 1 .

Tabel 1. Hasil Evaluasi Kegiatan PKM

\begin{tabular}{|c|c|c|c|c|c|c|c|}
\hline \multirow[t]{2}{*}{ No } & \multirow[t]{2}{*}{ Pertanyaan } & \multicolumn{3}{|c|}{ Sebelum } & \multicolumn{3}{|c|}{ Sesudah } \\
\hline & & $\begin{array}{l}\text { Ya } \\
\text { (3) }\end{array}$ & $\begin{array}{l}\text { Mungkin } \\
\text { (2) }\end{array}$ & $\begin{array}{l}\text { Tidak } \\
\text { (1) }\end{array}$ & $\begin{array}{l}\text { Ya } \\
\text { (3) }\end{array}$ & $\begin{array}{l}\text { Mungkin } \\
(2)\end{array}$ & $\begin{array}{c}\text { Tidak } \\
\text { (1) }\end{array}$ \\
\hline 1 & $\begin{array}{l}\text { Apakah anda pernah mengetahui Ancaman } \\
\text { Bencana seperti apa yang mungkin terjadi di } \\
\text { Sekolah }\end{array}$ & 8 & 1 & 2 & 11 & 0 & 0 \\
\hline 2 & $\begin{array}{l}\text { Apakah anda pernah mengetahui tentang } \\
\text { adanya Satuan Pendidikan Aman Bencana } \\
\text { (SPAB)? }\end{array}$ & 3 & 4 & 4 & 11 & 0 & 0 \\
\hline 3 & $\begin{array}{l}\text { Apakah anda pernah mengetahui tentang } \\
\text { Parameter Siaga Bencana? }\end{array}$ & 2 & 2 & 7 & 11 & 0 & 0 \\
\hline 4 & $\begin{array}{l}\text { Apakah anda pernah mengetahui tentang } \\
\text { Sistem Peringatan Dini? }\end{array}$ & 5 & 2 & 4 & 11 & 0 & 0 \\
\hline 5 & $\begin{array}{l}\text { Apakah anda pernah mengetahui tentang } \\
\text { Skala Gempa menurut MMI (Modified } \\
\text { Mercaili Intensity)? }\end{array}$ & 2 & 4 & 5 & 11 & 0 & 0 \\
\hline 6 & $\begin{array}{l}\text { Apakah anda pernah mengetahui tentang } \\
\text { bagaimana melakukan Siap Siaga Gempa? }\end{array}$ & 7 & 4 & 0 & 11 & 0 & 0 \\
\hline 7 & $\begin{array}{l}\text { Apakah anda pernah mengetahui tentang } \\
\text { jalur evakuasi? }\end{array}$ & 9 & 2 & 0 & 11 & 0 & 0 \\
\hline 8 & $\begin{array}{l}\text { Apakah anda pernah mengetahui tentang } \\
\text { "Titik Kumpul"? }\end{array}$ & 9 & 2 & 0 & 11 & 0 & 0 \\
\hline \multirow{2}{*}{\multicolumn{2}{|c|}{ Nilai Total }} & 45 & 21 & 22 & 88 & 0 & 0 \\
\hline & & \multicolumn{3}{|c|}{$75,38 \%$} & \multicolumn{3}{|c|}{$100,00 \%$} \\
\hline
\end{tabular}

Dari tabel tersebut tampak bahwa sebanyak 75,38\% menyatakan mengetahui dengan yakin tentang kebencanaan sebelum dilakukan pelatihan mitigasi bencana. Setelah dilakukan pelatihan mitigasi bencana, seluruh peserta (100\%) menyatakan mengetahui tentang kebencanaan. Dari hal tersebut tampak peningkatan pengetahuan sebesar 24,62\%, sehingga dapat dinyatakan kegiatan bermanfaat bagi peserta pelatihan. 


\section{KESIMPULAN}

Berdasarkan hasil kegiatan PKM yang dilakukan, maka kesimpulan yang dapat diambil adalah Penyusunan jalur evakuasi dan pemasangan penunjuk arah jalur evakuasi bermanfaat bagi mitra dalam mengurangi mengurangi resiko bencana dan dampak kerugian yang diakibatkan oleh bencana serta mampu memenuhi kebutuhan akreditasi dan peraturan daerah yang berlaku. Kemudian dari hasil evaluasi dari peserta terdapat peningkatan pengetahuan terkait kebencanaan sebesar $24,62 \%$

\section{UCAPAN TERIMA KASIH}

Kami mengucapkan terima kasih kepada Universitas Teknokrat Indonesia yang telah memberi dukungan pada kegiatan Pengabdian Kepada Masyarakat ini. Serta SMA Tunas Mekar Indonesia yang telah menjadi mitra pada kegiatan ini.

\section{DAFTAR PUSTAKA}

[1] M. Karimah, B. Kurniawan and Suroto, "Analisis Upaya Penanggulangan Kebakaran Di Gedung Bougenville Rumah Sakit Telogorejo Semarang," Jurnal Kesehatan Masyarakat, Vol. 4, No. 4, Pp. 698 - 706, 2016.

[2] Y. I. Setyaningrum and G. I. Sukma, "Pelatihan Pengurangan Risiko Bencana (Prb) Stikes Wch Bekerja Sama Dengan Sma/Smk Malang," Indonesian Journal Of Community Services, Vol. 2, No. 1, Pp. 92 - 100, 2020.

[3] S. W. Mustika, R. S. Wardani and D. B. Prasetio, "Penilaian Risiko Kebakaran Gedung Bertingkat," Jurnal Kesehatan Masyarakat Indonesia, Vol. 13, No. 1, Pp. 18 - 25, 2018.

[4] A. C. Windiyanti, K. Rustadi and Rudianto, "Analisis Zona Rawan Gempabumi Daerah Lampung Berdasarkan Nilai Percepatan Tanah Maksimum (Pga) Dan Data Accelererograph Tahun 2008-2017," Jurnal Geofisika Eksplorasi , Vol. 3, No. 2, Pp. 17 - 27, 2017.

[5] Pemerintah Kota Bandar Lampung, "Https://Peraturan.Bpk.Go.Id," 14 September 2015. [Online].

Available: Https://Peraturan.Bpk.Go.Id/Home/Download/105503/Perda\%20b.Lampung\%2005.2 015.Pdf. [Accessed 22 Juli 2021].

[6] Nurfajrida, M. Afifuddin and Abdullah, "Evaluasi Jalur Evakuasi Kebakaran Pada Kantor Bupati Nagan Raya," Teras Jurnal, Vol. 9, No. 2, Pp. 102 - 113, 2019.

[7] P. S. Atmodjo, S. Sangkawati and A. B. Setiaji, "Analisis Efektivitas Jalur Evakuasi Bencana Banjir," Media Komunikasi Teknik Sipil, Vol. 21, No. 1, Pp. 23 - 34, 2015.

[8] W. Sujatmiko, "The Application Of The Standard Of Fire Safety Evacuation In Building In Indonesia," Jurnal Permukiman, Vol. 11, No. 2, Pp. 116 - 127, 2016.

[9] R. Daud, S. A. Sari, S. Milfayetty and M. Dirhamsyah, "Penerapan Pelatihan Siaga Bencana Dalam Meningkatkan Pengetahuan, Sikap, Dan Tindakan Komunitas Sma Negeri 5 Banda Aceh," Jurnal Ilmu Kebencanaan (Jika), Vol. 1, No. 1, Pp. 26 - 34, 2014.

[10] T. N. Utami and M. Nanda, "Pengaruh Pelatihan Bencana Dan Keselamatan Kerja Terhadap Respons Persepsi Mahasiswa Prodi Ilmu Kesehatan Masyarakat," Jurnal Jumantik , Vol. 4, No. 1, Pp. 83 - 100, 2019. 